
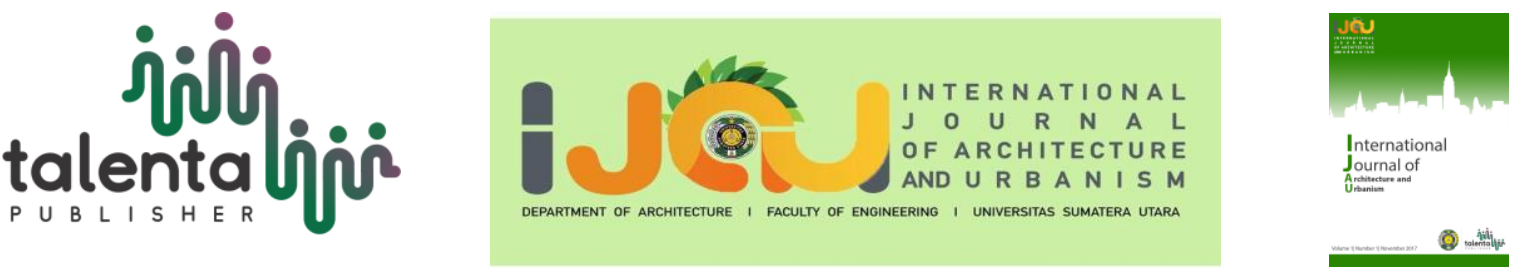

\title{
Designing Port Passenger Terminal in the Meat Village as Ecotourism Area with Neo Vernacular Architecture Approach
}

\author{
Fitri Rahmawati Nasution $^{1 *}$, Moehammed Nawawiy Loebis ${ }^{1}$ \\ ${ }^{I}$ Department of Architecture, Faculty of Engineering, Universitas Sumatera Utara, Medan, Indonesia
}

\begin{abstract}
This journal is essential for social, economic, and government in the Meat Village. It is about a potentially marine tourism destination, located in Meat Village, Tampahan District, Toba Samosir Regency, North Sumatra Province. As one of the tourism destinations, this village needs to be developed, especially water transportation, which is supported by Lake Toba's natural resources. But it has been replaced by land and air transportation. On the other hand, water transportation has its privilege, namely giving a sense of being united with nature and listening to the gentle sound of water, which cannot be felt if using land or air transportation. Therefore, it requires a passenger port to facilitate tourists in accessing this tourism village through water transportation. This port consists of a passenger terminal that accommodates passengers' departure and arrival. The method used in site selection is done through discussion of primary data, namely data sources that directly provide data to data collectors and secondary data, that is, data that does not directly provide data to researchers, through other people or analyzed documents and concluded. The result of the methodology used is, this passenger terminal needs the Neo Vernacular Architecture approach for the design. Because the village has aspects of the past, such as Batak Toba culture and mythology that need to be preserved and introduced to the present as long-term projections for the future. This is useful to make the building becomes part of the Meat Village community.
\end{abstract}

Keyword: meat village, passenger terminal, port

Received 10-01-2020 | Revised 01-02-2020 | Accepted 12-02-2020

\section{Introduction}

Indonesia is a country that is rich in beautiful nature. This beautiful nature has an essential role in the development of the tourism sector in Indonesia. As a form of development improvement in Indonesia, the government has set ten priority tourism destinations in Indonesia, one of them is Lake Toba. As a result, the government issued Presidential Regulation No. 81 of 2014 concerning Spatial Planning for Lake Toba and Surrounding Areas. One of the regulation

*Corresponding author at: Department of Architecture, Faculty of Engineering, Universitas Sumatera Utara, Jalan Perpustakaan Gedung J07, Medan 20155, Indonesia

E-mail address: fitrinasution21@gmail.com

Copyright (C) 2020 Published by Talenta Publisher, 
contents states that Meat Village in Tampahan Sub-District is ecotourism, cultural heritage, science tourism, and water tourism area [1].

Therefore, facilities and infrastructures in Meat Village need to be developed, especially water transportation, which is supported by Lake Toba's natural resources. But it has been replaced by land and air transportation. On the other hand, water transportation has its privilege, namely giving a sense of being united with nature and listening to the gentle sound of water, which cannot be felt if using land or air transportation.

To accommodate activities related to water transportation, it is necessary to design a port passenger terminal in this village. The design uses the Neo-Vernacular Architecture approach, which is created by taking aspects from the past to be represented to the present as a projection for the future so that the building becomes part of the Meat Village community.

\section{Literature Review}

According to Government Regulation of the Republic of Indonesia No. 69 of 2001 concerning Port, the port is a place consisting of land and water around it with specific limits as a place of government and economic activities that are used as a place for ships to dock, anchor, passengers and loading and unloading of goods that are equipped with shipping safety facilities and port support activities as well as a place for Intra and inter mode transportation [2]. In terms of usage, the port consists of six types, namely a fishing port, an oil port, a port of goods, a passenger port/terminal, a mixed port, and a military port [3]. According to Law No. 22 of 2009 concerning Traffic and Road Transportation, a passenger terminal is a road transportation infrastructure for picking up and dropping passengers, intra and or intermodal transportation modes and arrangements for the arrival and departure of public vehicles [4].

Neo-Vernacular Architecture is a contemporary interpretation of vernacular buildings. To preserve vernacular architecture, it is necessary to involve it in the flow of modern life, by introducing new functions and objects, that are not known yet by the original (vernacular) architectural structure. This new structure is primarily intended for tourism or culture, but lately also for other functions that strengthen the local economy. Because this is a dialogue between old and new, the implementation must be done carefully. Because sometimes, new features, despite successful architectural interventions, can experience setbacks or tarnish living cultures and even contribute to a gradual degradation of authenticity (which often occurs in tourist areas).

According to Daniel Libeskind, the combination of the two contradictions, between old and new, is an embodiment of a journey process (movement). Like a photo frame that keeps a significant memory of the events that are enshrined, it can be arranged into a complete story. Alternatively, conversely, a film is composed of many series of images recorded per second, to 
form a unity. Each travel process has its memory, which is used as a material for reflection and contemplation for the leap to the next operation (the transformation process). The embodiment of the transformation process implies Emotional Recall, which is, when the five senses are aroused in certain circumstances and situations, the memory jumps to a different time due to stimuli that open the entrance of memory fragments or visions to go forward, from here the characters and expressions show their form in the process of transformation that keeps repeating [5].

Neo-Vernacular Architecture between one place and another is different. It is because every site has its soul or Genius Loci. Genius Loci is a Roman concept. According to the ancient Roman belief, every 'independent' creature has its genius, its protective spirit. This spirit gives life to people and places, accompanies them from birth to death, and determines their character or essence. Even the gods have their genius, a fact that illustrates the fundamental aspect of the concept [6].

According to Norberg Schulz, 'a concrete picture' as an interpretation of our experience is essential. Therefore, the phenomenological challenge lies in reviving the poetic dimension of these things and rebuilding the lost relationships between the various elements that compose our world. Specifically, Norberg Schulz emphasizes the relationship between the human-made world and the natural world, which has been proven historically in multiple places and environments from around the world.

This relationship is created through three phases, namely visualization, complement, and symbolization. The final step, symbolization, plays a more critical role in the concretization of the meaning of a place. The essence of the definition is incorporated into the building's design in the site so that the existential purpose of the building is to make the area becomes a place, which is to uncover potential meanings present in a given environment. The power of metaphor/symbolization has been valued by respected architectural educators, who even regard it as a cornerstone of imagination. In broader terms, a metaphorical channel can benefit every creator. It provides an opportunity to see works expressed in other light that forces the creator to investigate new questions and produce new interpretations.

Metaphors can greatly help in generating new concepts that are substantial to build authenticity. Authenticity is the general identity of a particular building, which must be understood and followed by every architect in designing the building. Metaphor consists of three main categories, namely Intangible Metaphor, Tangible Metaphor, and Combined Metaphor. Intangible Metaphor is a metaphor obtained implicitly through certain concepts, ideas, human conditions, or qualities (individuality, naturalness, community, tradition, culture). Tangible Metaphor is a metaphor derived from several visual or material characters (houses as castles, temple roofs like the sky) [7]. While Combined Metaphor is a combination of intangible and tangible metaphors, in which conceptual and visual overlap as material from the point of 
departure, and the visual is detecting the virtues, qualities, and foundations of certain visual containers.

\section{Methodology}

The method used in solving design problems in the design of the Port Passenger Terminal in the Meat Village Ecotourism Area is descriptive, namely by collecting data, both primary and secondary data. Data collection consists of background, objectives, and problems related to design.

The next stage is the design analysis. At this stage, analyzes are produced based on direct observations in the field. The last step is the design concept. This concept is made through observing the needs of users, the environment, analysis, and studies are done, the problems found, and the solutions obtained.

\section{$4 \quad$ Result and Discussion}

\section{Project Description}

The title of this project is Designing Port Passenger Terminal in the Meat Village as Ecotourism Area with Neo-Vernacular Architecture Approach. This project is a form of structuring the Meat Village area as one of the ecotourism areas located in Tampahan Sub-District, Toba Samosir Regency. As an ecotourism area, Meat Village needs a port to increase convenience and provide alternative access for tourists and improve the quality of its water tourism.

Tampahan has an area of $24.45 \mathrm{~km}^{2}$. This sub-district consists of 6 villages. Those are Meat Village, Tarabunga Village, Lintong Nihuta Village, Tangga Batu Barat Village, Tangga Batu Timur Village, and Gurgur Aek Raja Village. Meat Village is the lowest village with 979 meters high above sea level, with an area of $3.00 \mathrm{~km}^{2}$ (Figure 1).

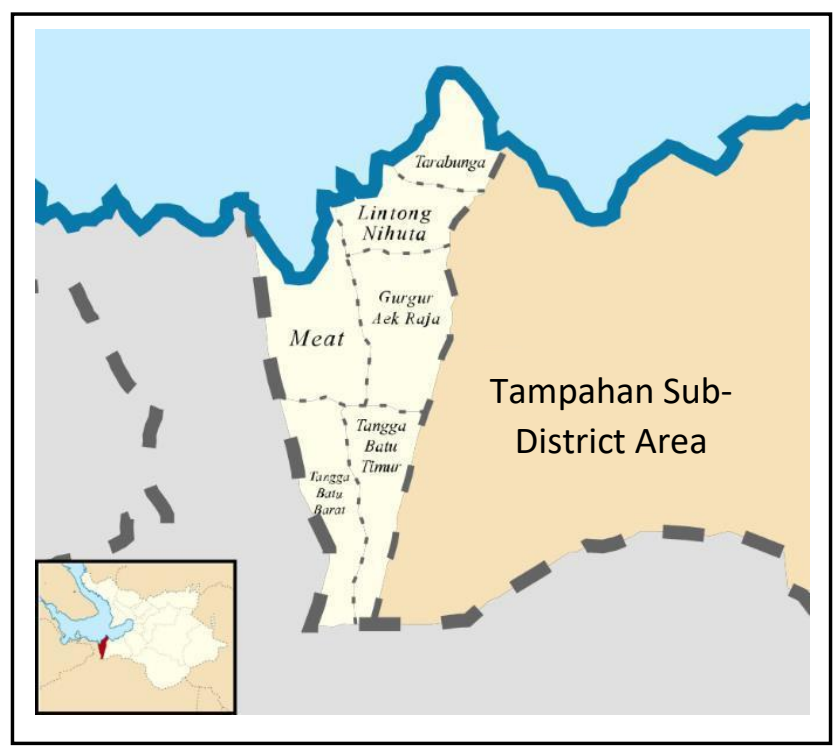

Figure 1 Map of Tampahan Sub-District Area 
Tampahan Sub-District area bordered by Lake Toba on the northside. While on the eastside, it bordered by Balige District. On the southside, is bordered by North Tapanuli Regency. And it bordered by North Tapanuli Regency on the westside. The area of the design site is 2 hectares. On the northside, is bordered by Lake Toba. On the eastside, it bordered by The Siahaan motel. It bordered by agricultural fields on the southside and bordered by agricultural fields on the westside (Figure 2).

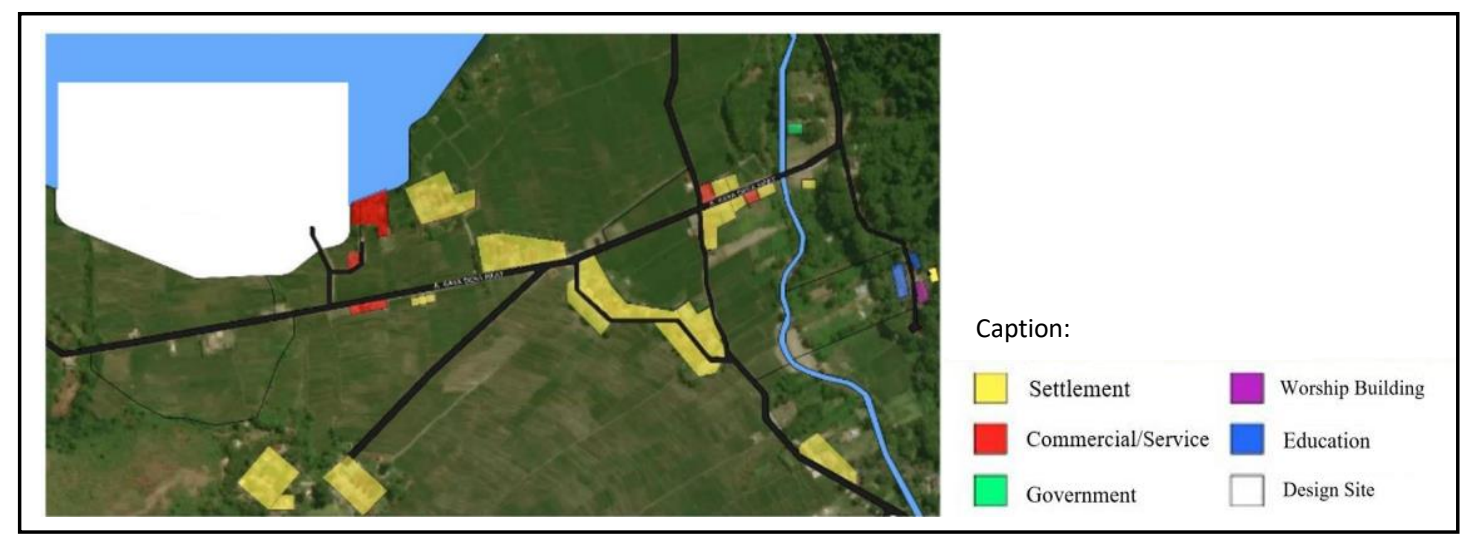

Figure 2 Design Site and the Environment

\section{Basic Concept}

The Toba community is influenced by the Malim religion, before the entry of Christianity and Islam. This religion left various beliefs and cultures for Toba people. According to Malim's believers, the God who created the universe was the God Almighty called Debata Mulajadi Nabolon, which in Batak language, Debata means "omnipotent" and "enormous." $\mathrm{He}$ is the almighty creator, almighty, and the beginning of everything that exists. Then Debata created the gods and appointed them as his helpers, one of whom was Si Boru Saniangnaga, the goddess of water, who was obliged to believe. Saniangnaga is in charge of mastering all forms and types of water on earth. Debata gave him the power to manage water for the benefit of humans and other creatures and determine the livelihoods of farmers (irrigation) and fishermen (big waves) [7].

According to the Malim religion, Saniangnaga is always believed to be present in water. A snake describes his form [7]. Therefore, to symbolize the Toba people's trust in Si Boru Saniangnaga, the basic concept of the design of this port is to take the spirit of Saniangnaga. In which, the building consists of one mass that seems to be two. It is because only the two ends of the building that arise to the surface of the lake, while the middle is in the water. One end looks like protruding into the water, and the other end looks like emerging from the lake. This concept symbolizes Saniangnaga's power over water, where she controls water, from the surface to the deepest part of the water. This symbolization is to make the Toba people initiative to maintain and take care of this port because of they believe in the presence of the goddess who determines the fate of their work related to water (Figure 3). 


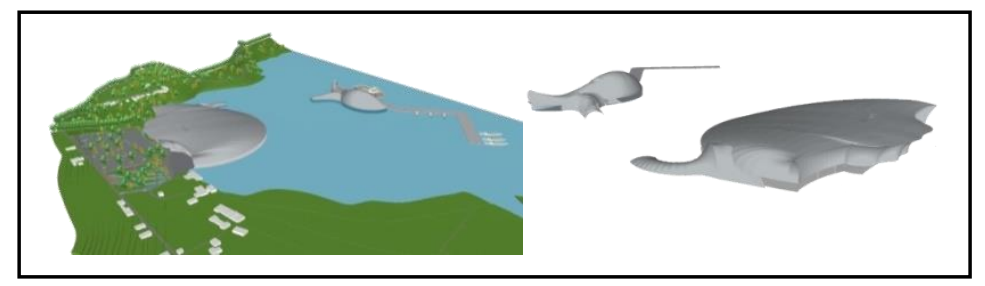

Figure 3 Basic Concept of the Mass

The concept presented above is the implementation of intangible metaphor, which symbolizes the essence of Si Boru Saniangnaga's spirit. In addition to the intangible metaphor, the design of the passenger terminal also implements tangible metaphor, by making the concept of the mass composition of a giant cobra formation. In which, the mass that seemed to protrude into the water is formed like a snake's head, and the building that seemed to emerge from the lake is like a snake's tail. The corridor that connects the two buildings, which is entirely in the water, is like the body of the snake. This mass' scale is much larger than the human's and surrounding masses' level, to symbolize the size of the giant snake.

\section{Activity System Concept/ Space Program}

Based on observations, the Toba community is a group of people who like to gather and tell stories while eating and drinking. As seen in the Ajibata port in Parapat, there is no particular room used as a departure room. In which the departure room is in the form of stalls around the harbor. The role of food and dining in the religious life of Toba contains the spirit needed by Tondi and the energy for the body. Ceremonial dining activities are always carried out in the most sacred space. If the ritual is carried out inside the house, then the dining activity is carried out in the middle of the house (Tonga Nijabu) on a clean mat (Lage Matiar). Therefore, the concept of the spatial program is designed by collaborating between established standards and Toba community culture.

\section{Exterior Design Concept}

Exterior area consists of three main zones, namely the parking zone, green open space zone, and the passenger port zone (Figure 4).

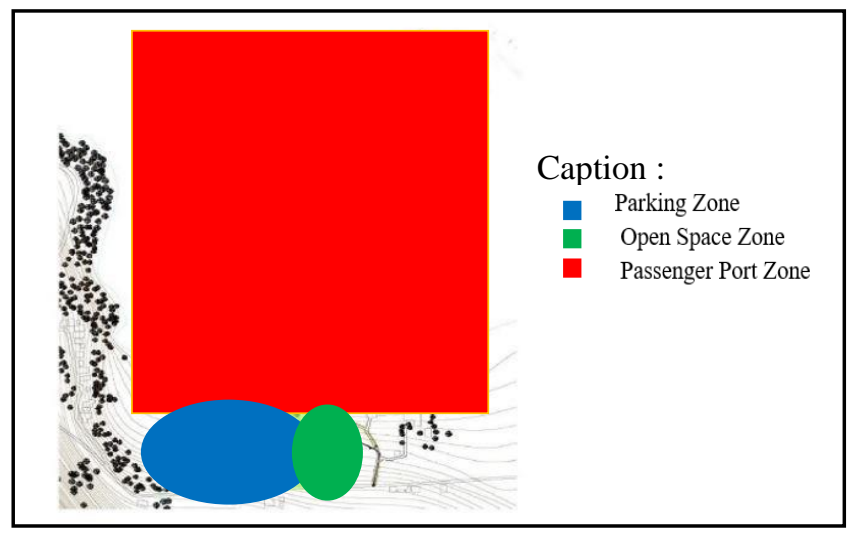

Figure 4 Exterior Zoning Concept 
The parking zone consists of parking lots for cars (Figure 5), motorcycles (Figure 6), and buses (Figure 7) along with the circulations.

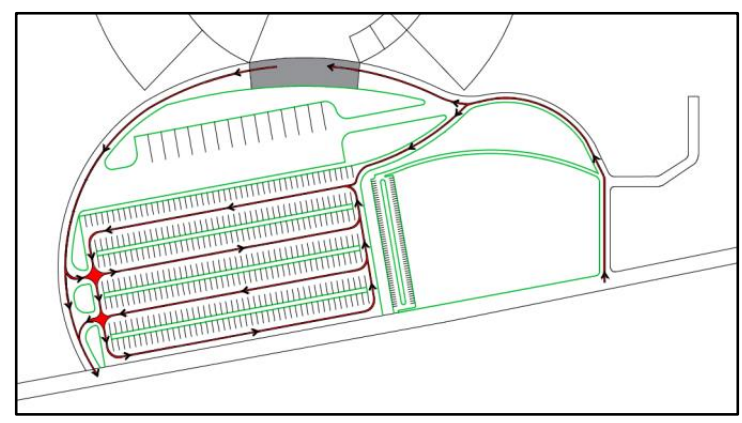

Figure 5 Car Circulation

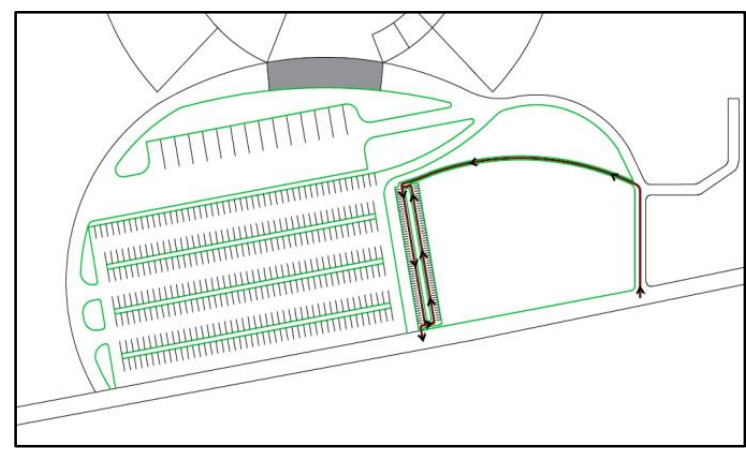

Figure 6 Motorcycle Circulation

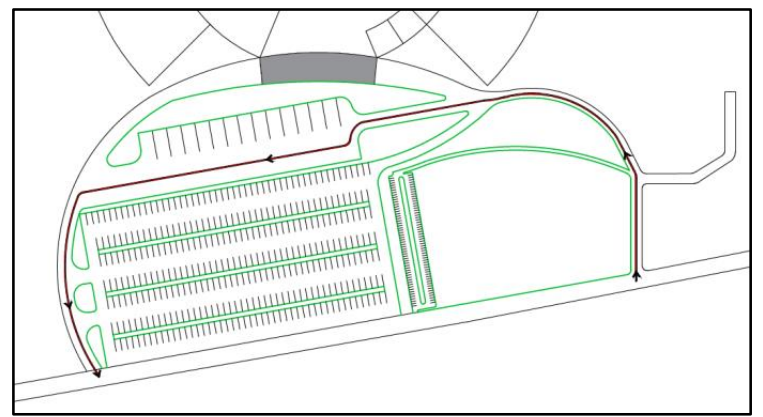

Figure 7 Bus Circulation

Green open space zone consists of trees, fish ponds, and pedestrian paths. The port zone consists of a giant mass that extends into the water (Figure 8).

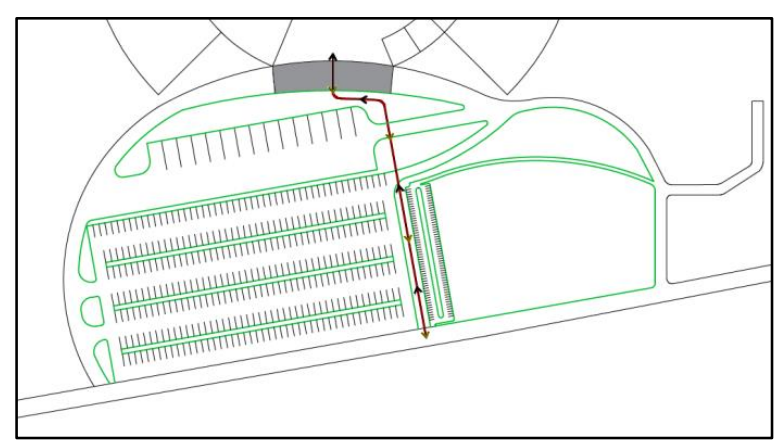

Figure 8 Pedestrian Path 


\section{Interior Design Concept}

Based on the Indonesian National Standard of Facility and Equipment at the Port for International Cruise and Passenger Service, the spatial and circulation blocks of passengers and escorts/pickers at the international terminal are as follows (Figure 9).

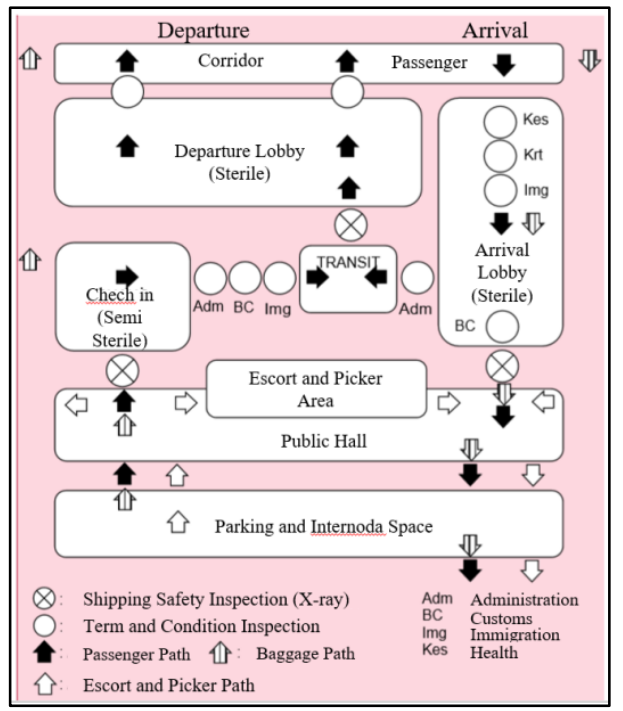

Figure 9 The Spatial and Circulation Block of Passenger and Escort / Picker at the International Terminal

Based on the international standard, the concept of interior zones of the port passenger terminal is as follows (Figure 10).

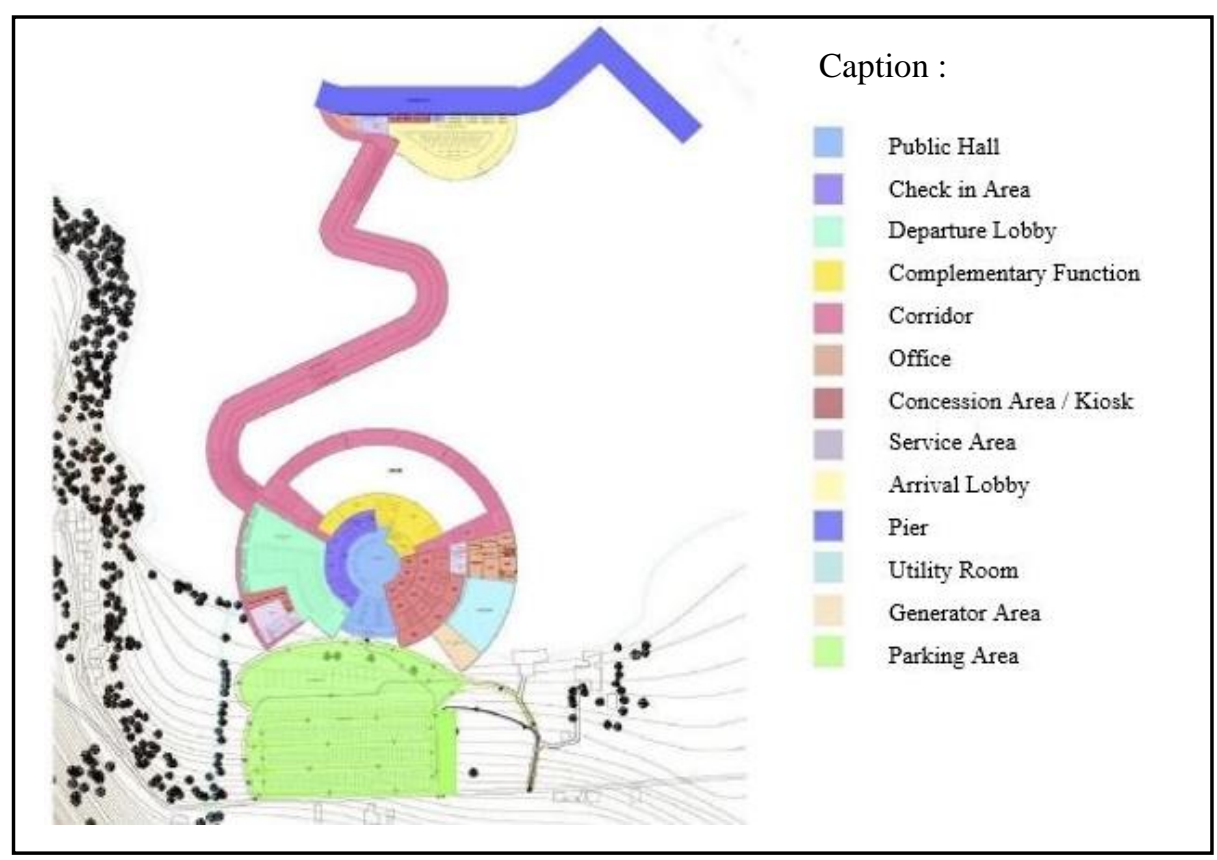

Figure 10 Interior Zoning Concept 
As an implementation of the snake's dynamic behavior, dynamic spaces are symbolized horizontally (left and right) and vertically (up and down). This metaphor is called the Intangible Metaphor (Figure 11).

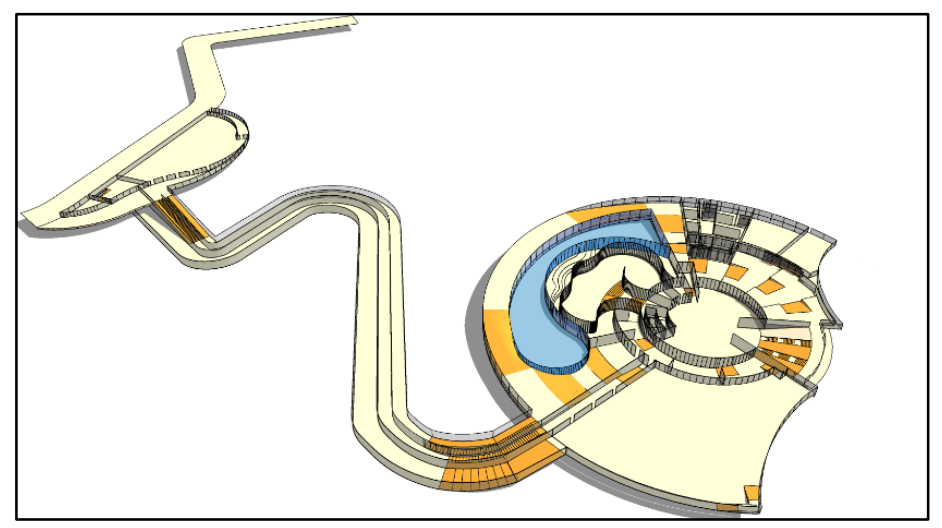

Figure 11 Dynamic Spaces

This port passenger terminal consists of two main circulations, namely departure circulation and arrival circulation. These two circulations look like the following picture (Figure 12).

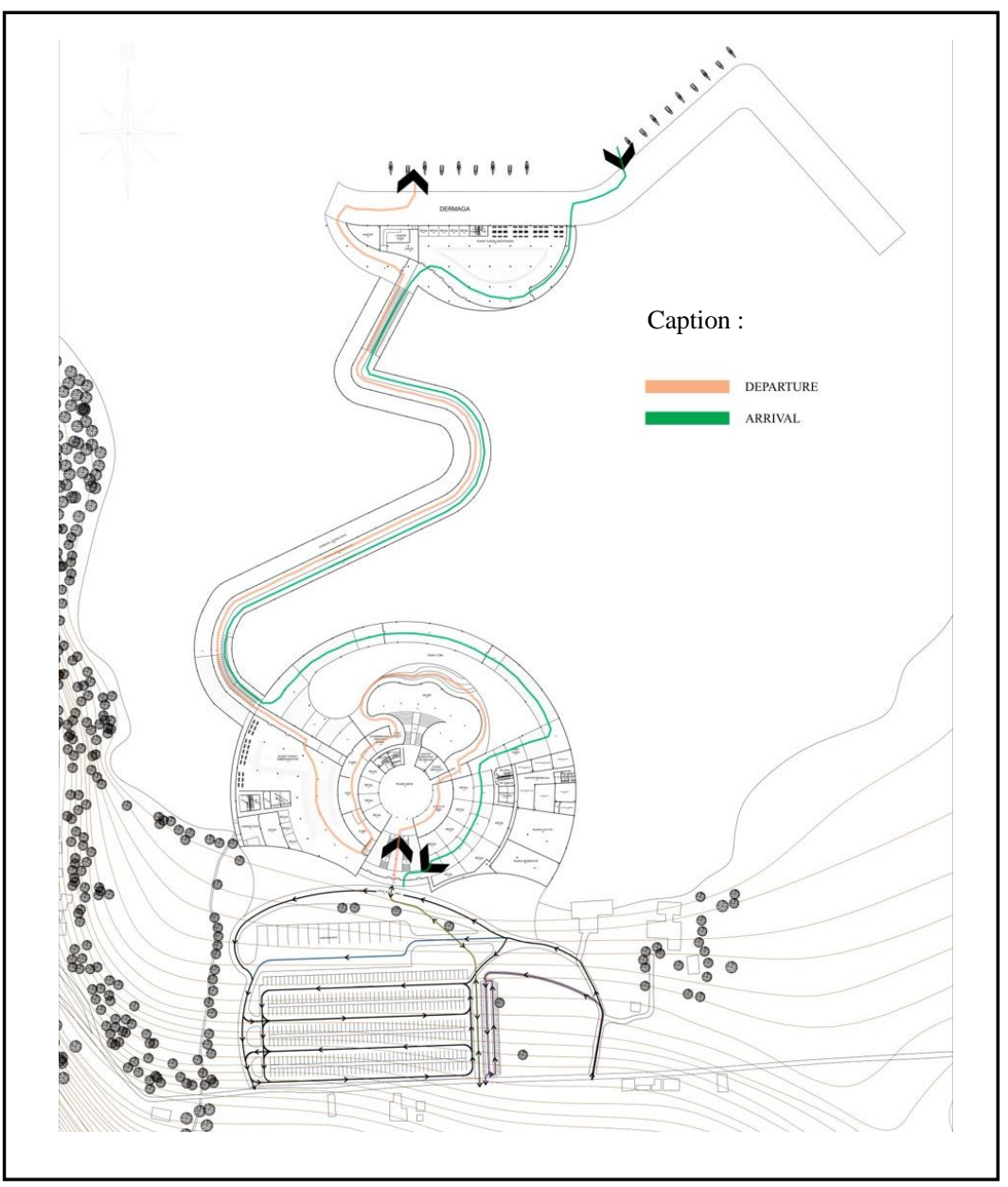

Figure 12 Departure and Arrival Circulations 
The interior design also saw that Lake Toba is part of the building. Lake Toba is in the interior of the building as an embodiment of the intangible metaphor, that water is an element protected by Si Boru Saniangnaga (Figure 13).

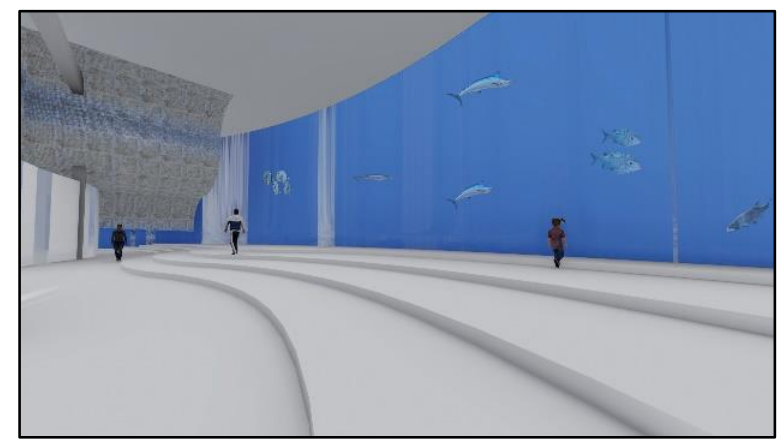

Figure 13 Lake Toba as Part of the Building

Especially when passing through the corridor, passengers feel like under the protection of $\mathrm{Si}$ Boru Saniangnaga along with other aquatic creatures (Figure 14).

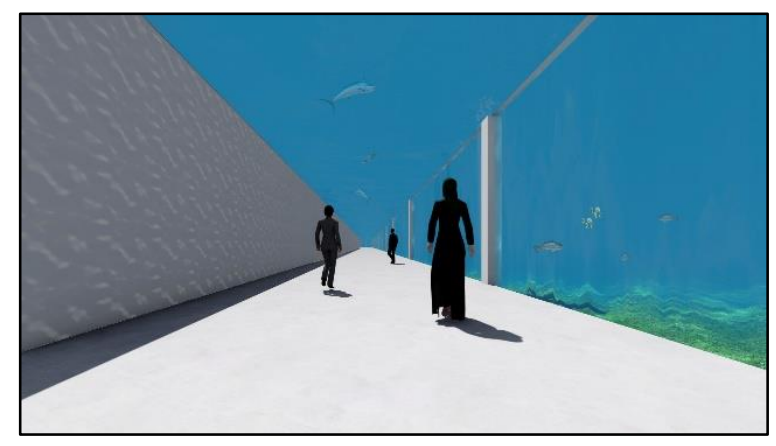

Figure 14 Corridor Atmosphere

To implement the Toba people nurture, who like to mingle while dining, and symbolize the importance of dining for those where ceremonial dining activities are always carried out in the sacred space, that is in the middle of the house (Tonga Nijabu), then the departure and arrival lobbies are provided with a place for passengers to eat while socializing. It aims to recall the nurture so that they exist in it (Figure 15).

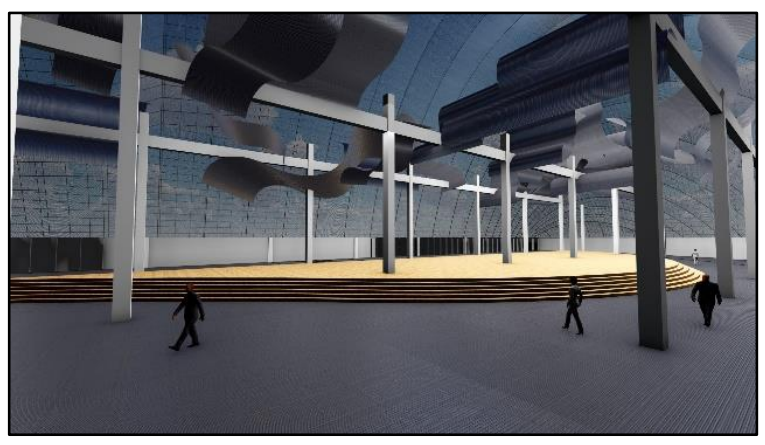

Figure 15 Arrival Lobby Atmosphere 


\section{Conclusion}

The Saniangnaga Port Passenger Terminal, located in Meat Village, Tampahan Sub-District, Toba Samosir Regency, North Sumatra Province, is designed to revitalize water transportation activities. With the reoperation of this transportation, a sense of need arises, which improves the concern of water, in this case, Lake Toba.

To make the passengers feel they exist in it, the design of the passenger terminal uses the Neo Vernacular architecture approach. This architecture has several theories. The three arguments used in this design are Genius Loci, Movement, and Emotional Recall. Genius Loci is a theory introduced by Christian Norberg Schulz, which states that all places have a soul. The soul (spirit) has two aspects, namely nurture (nature) and culture (human). Movement is a journey process of time by recalling the history to the present as a projection to the future. Emotional Recall is an impact caused by the change of time, where someone's memory is flashed back to the past, thus making him/her exist in that place.

From the nurture aspect, the design of this port passenger terminal focuses on the water element. By representing the mythology of Toba people, who believe that there is a goddess of water authority named Si Boru Saniangnaga, she is believed to be in the form of a giant snake. Therefore, the formation of this mass uses the metaphor of the snake, both tangible and intangible metaphors.

From the cultural aspect, this design applies the habit of the Toba people who like to eat while socializing. Moreover, the dining and food have an essential meaning. Ceremonial dining activity is carried out in the sacred space, namely Tonga Nijabu, which is in the middle of the house. Therefore, in every social place, such as the arrival and departure lobbies, then there is a place to eat in the middle of the room, as a symbolization of the ceremonial dining activities.

\section{Acknowledgment}

This research is about one of the mythologies of Toba people which is represented and symbolized in the design as one of the ways to preserve local wisdom. The author thanks the Department of Architecture in North Sumatera University for the guidance in writing this research.

\section{REFERENCES}

[1] Peraturan Presiden Republik Indonesia. (2014) Peraturan Presiden (PERPRES) tentang Rencana Tata Ruang Kawasan Danau Toba dan Sekitarnya.

[2] Preaturan Presiden Republik Indonesia. (2001) Peraturan Pemerintah Republik Indonesia Nomor 69 Tahun 2001 Tentang Kepelabuhanan.

[3] Bambang Triatmodjo, Perencanaan Pelabuhan. Yogyakarta : Penerbit Beta Offset 
Yogyakarta, 2010.

[4] Peraturan Presiden Republik Indonesia. (2019) Undang Undang Republik Indonesia Nomor 22 Tahun 2009 Tentang Lalu Lintas dan Angkutan Jalan.

[5] H. A. Maahury, D. Erdiono, and \& A. S. Sembel, "Sekolah Tinggi Sinematografi 'Implementasi Micromegas Daniel Libeskind'," 2015.

[6] Norberg-Schultz Christian, Genius Loci: Towards a Phenomenology of Architecture. New York: Rizzoli, 1979.

[7] Ibrahim Gultom, Agama Malim di Tanah Batak. Jakarta : Penerbit Bumi Aksara, 2010. 